\title{
PUBLIC HEALTH SERVICES
}

\section{Community Health and the Law}

\author{
GEORGE A. MCKRAY, LL.M., M.P.H., M.S.
}

$\mathrm{T}$ THE PREMISE for this institute, that the public health official is increasingly involved in legal matters, holds true in the area of community health. My objective is to examine ways in which the three basic types of law bear upon community health administration (1-3). I shall attempt to show in a general way how constitutional law, administrative law, and common law apply to the field and then cite some specific, to my mind, trend-setting cases.

\section{Constitutional Law}

Constitutional law is the basic law of the land. Examination of constitutional law reveals the authority for the enactment of health laws, the scope of power assigned to the Federal, State, and local levels, and the limitations of possible governmental health regulation. I will touch briefly on these topics and discuss how the philosophy behind interpretation of constitutional law relating to public health has evolved during the past 50 years.

Jurisdiction in health regulation. All health statutes are enacted according to the specific powers invested in govermment. Federal activity $(2 a, 3 a)$ is based upon the enumerated powers given in the Federal Constitution which are not described in detail. The Constitution does not specifically grant any direct power to provide public health services; Federal activity in this area has largely been predicated on a broad interpretation of the two constitutional clauses which prescribe that the Federal Govermment shall provide for the general welfare and shall regulate interstate and foreign commerce.

Mr. McKray is a lecturer in public health and medical administration, University of California, Berkeley.
Under the welfare clause the Federal Government has established the Public Health Service and the Children's Bureau, which both use Federal grant-in-aid funds to subsidize State and local health programs. Under the commerce clause, the Federal Government has acted in such areas as international and interstate quarantine; control of foods, drugs, and cosmetics; sanitary supervision; collection of vital statistics; and hospitalization of merchant seamen and narcotic addicts, and has assumed direct responsibility for the health of the American Indians.

To a lesser extent, other clauses of the Constitution have been interpreted to give the Federal Government a legal basis to act in fields relating to health. The provision for the establishment of "post offices and post roads" has led to the right of the Federal Government to bar from the mails material deleterious to the public health. The power "to raise and support armies" and to "provide and maintain a navy" logically placed responsibility for the health of the Armed Forces and their dependents in the hands of the Federal agencies. Complete and exclusive jurisdiction over the inhabitants of the seat of the national government, the District of Columbia, is also specified.

In addition, the Federal Constitution provides that Congress shall have the power "to make all laws which shall be necessary and proper for carrying into execution the foregoing powers."

Sovereignty resides within the State rather than within the national government $(2 b, 3 b)$. Police power is inherent in the exercise of sovereignty and extends to all public needs, such as the right to pass laws which are reasonably necessary for the protection and preservation of the peace, safety, health, morality, and general welfare of its citizens. Thus public health 
jurisdiction at the State level is more specific and broader than at the Federal level.

The State is the fundamental source of power for all local governments (4). Each State through its constitution and legislature establishes the basic local political unit-the county being the chief unit in the Far West-to carry out administrative and governmental functions within its jurisdiction. Cities as municipal corporations are also the legal creations of the State. Thus, in the county and city, the scope of community health activity is dependent upon the will of the State in which they are located.

Limitations of regulatory power. The scope of power to be exercised by the Federal and State governments in the public health field is generally delineated by constitutional law (3c). The Federal Government may not meddle with health regulations promulgated by the States according to their police powers because of the Constitution's implied "doctrine of intergovernmental immunities" restraining either branch from interfering with the other. On the other hand, health legislation affecting interstate and foreign commerce is the province of the Federal Government only, except when the matter is local in nature and the Federal Government has not acted. Thus, a State can pass an antipollution measure requiring ships engaged in interstate commerce to cap their smokestacks (5).

At times the Federal and State governments may exercise powers in the health field concurrently. However if inconsistencies arise, the Federal statute shall always take precedence over the State statute because of the fact that the Federal Constitution states: "This Constitution and the laws of the United States... shall be the supreme law of the land."

All branches of the government are limited insofar as their program of health regulation might constitute an infringement upon individual liberty. Generally speaking, health regulations of State and Federal agencies may not violate the principles incorporated in the Bill of Rights given in the first eight amendments to the Federal Constitution. For example, health laws may not impinge upon freedom of religion as expressed in the first amendment, or upon prohibition against illegal searches and seizures as given in the fourth amendment.
No Federal statute may violate the due process clause of the 5th amendment, nor may any State violate that of the 14th amendment. These amendments guarantee individuals the right not to be deprived of their life, liberty, or property without due process of law. The U.S. Supreme Court has interpreted the due process clause of the fifth amendment to include the concept of equal protection of laws and the prohibition against vagueness of laws, although the Federal Constitution expressly applied these safeguards at the State but not at the Federal level.

In reviewing specific health-regulative statutes, the courts often run into the problem of reconciling the sometimes contradictory principles of individual liberty and the general good. In these instances the courts face the task of attempting to balance the natural rights of an individual against the interest of society.

Constitutional developments in the health field. The first important case in the field of public health was Jacobson v. Massachusetts $(3 d, 6)$, decided by the U.S. Supreme Court in 1905. This case set a precedent, thereafter often followed, that public health programs established under the pressure of great danger are constitutional.

Following are the details of the case. Under a Massachusetts statute the Board of Health of the city of Cambridge adopted a regulation for the compulsory vaccination and revaccination of its citizens for smallpox because of the possibility of an epidemic. Jacobson refused to be vaccinated and was arrested for a violation of the regulation. He pleaded not guilty, his defense being that the regulation violated his personal liberty without due process of law because vaccination was contrary to his religious belief and was a deprivation of his fundamental right to care for his own health. The U.S. Supreme Court held that Cambridge, in making vaccination compulsory, was reasonably exercising its police power. Mr. Justice Harlan, who gave the opinion, stated :

There is, of course, a sphere within which the individual may assert the supremacy of his own will and rightfully dispute the authority of any human government, especially of any free government existing under a written constitution, to interfere with the exercise 
of that will. But it is equally true that in every wellordered society charged with the duty of conserving the safety of its members, the rights of the individual in respect of his liberty may at times, under the pressure of great danger be subjected to such restraints, to be enforced by reasonable regulations, as the safety of the general public may demand. [Italies supplied.]

Today the "doctrine of great danger," as a criterion for deciding the constitutionality of public health programs, is being challenged by the "doctrine of public need." The new criterion, proposed in a series of cases involving fluoridation of water, has both proponents and critics ( $\%$ ).

Kaul v. City of Chehalis (8) is typical of the water fluoridation cases. In this case a taxpayer sought to enjoin Chehalis, Wash., from fluoridating the city water supply pursuant to an ordinance adopted by the city. The plaintiff Kaul raised arguments concerning freedom of religion, forced medication, discrimination against adults who do not benefit therefrom, illegal practice of medicine (by the city), violation of the pure food and drug acts, and breach of contract to supply pure water. The court readily dismissed all the arguments except the issue involving deprivation of a fundamental right to care for one's own health or "forced medication." The decision on this issue was a narrow 5-to-4 in favor of the city of Chehalis.

The majority $(8 a)$ in the Kaul case relied, in part, upon the majority opinion given in Dowell v. Tulsa:

We think the weight of well-reasoned modern precedent sustains the right of municipalities to adopt such reasonable and undiscriminating measures to improve their water supplies as are necessary to protect and improve the public health, even though no epidemic is imminent and no contagious disease or virus is directly involved (citing authorities). Where such necessity is established, the courts, especially in recent years, have adopted a liberal view of the health measures promulgated and sought to be enforced.

The minority opinion ( $8 b)$ criticized the majority's view that public need constituted sufficient reason to limit individual liberty and advocated return to the standard set in Jacobson v. Massachusetts.

In . . . [their] . . . process of reasoning, the majority, I believe, overlooks a very important limitation upon the exercise of the police power, which is that, whether the police power is being exercised for the protection of public health or any other reason, it may not extend to the point of impairing a constitutionally guaranteed personal right, unless justified by "pressure of great danger." . . . It is because of this limitation on the exercise of the police power that the courts have drawn a distinction between contagious and non-contagious diseases. . . . The principle being established by the majority opinion, even more than the specific deprivation of personal liberty here accomplished, warrants deep concern. The case before us deals with what some will regard as a relatively minor aspect of dental health. But the principle announced is not so limited. It would be equally applicable if fluoridation (or iodination) was being relied upon to counteract goiter or any other noncontagious bodily malady. What future proposals may be made to treat non-contagious diseases by adding ingredients to our water supply, or food, or air, only time will tell. When that day arrives, those who treasure their personal liberty will look in vain for a constitutional safeguard. The answer will be: "You gave the constitution away in the Kaul case."

The apprehensions expressed by the minority in the Kaul case are generally being disregarded. Since 1953, when the California Court of Appeals held valid an ordinance of the city of San Diego authorizing the fluoridation of its water supply (9), fluoridation ordinances have been ruled constitutional by the high courts of Louisiana (10), Oklahoma (11), Ohio (12), Washington $(8,13)$, Wisconsin (14), Oregon (15), Iowa (16), Missouri (17), and Florida (18). Only the courts of North Dakota (19) and Indiana (20) voiced qualified objections. The U.S. Supreme Court has refused to hear fluoridation cases on five occasions.

As the courts struggle with the problem of individual rights versus the public good in specific cases, two distinct and somewhat opposing judicial trends may be presently observed. The U.S. Supreme Court has vigorously adopted and applied a presumption of constitutionality to legislation brought before it for review-to the effect that the court will not substitute its own discretion for that of the legislature. Thus the climate is favorably disposed toward experimentation by State legislatures in the enactment of social and other legislation under their police powers. On the other hand, some State courts have swung the other waytending more and more to investigate thoroughly whether or not a police power statute brought before it which impinges upon an 
individual's fundamental rights has a rational basis to the end it seeks to accomplish.

\section{Administrative Law}

Administrative law defines the manner in which the government carries out its functions. It comes into being as the legislature creates governmental agencies to handle its everincreasing operations and delegates certain powers to them. Administrative law involves four types of police power. The first, directing power, is exercised by the legislature; the other three, discretionary, licensing, and summary, are exercised by the agency under mandate from the legislature.

Directing power. The most fundamental type of health legislation is enacted when a legislature establishes an official organization to deal with public health. The legislature exercises its directing powers in outlining the scope of the health agency's activities $(21,3 e)$. The States vary widely as to the details of their health laws, but the administrative hierarchy generally is topped by a supervisory State board of health, a health officer, and his staff. Local health departments which are responsible to local health boards as well as to the State board are normally established. State health authorities usually are empowered to act in any locality within the State in the absence of a local health department or upon the failure of the local authority to take action.

The high cost of administration is responsible for a current trend in many States to establish health districts serving more than a single local governmental area. The legal problems of merger or consolidation of health facilities involve the proper use of directing power and are illustrated by Bacus v. Lake County (22).

Bacus, as a taxpayer, brought a suit challenging the legitimacy of a Montana statute providing for the creation, without the vote or approval of taxpayers, of health districts not coinciding with previously established political subdivisions. In 1958 a health district had been established from two adjoining counties by their respective county commissioners, pursuant to the 1947 State statute, in order that the counties might pool their resources. In respect to the plaintiff's main objection, the court ruled that his case was without merit; that is, that the
Montana legislature had the directing power to establish the procedure under which local health districts might be created. The court stated (22a) :

A county or district board of health cannot be classified or termed a political subdivision of the State. At most, it could only be defined as a department of the State or as an agency of the executive branch of the State government. This provision for health districts embracing more than one county . . . is only a provision providing for an effective method of cooperation among the counties of Montana with respect to health problems. However, the counties themselves are still the political subdivisions of the State of Montana which have entered into this cooperative measure.

Discretionary power. In the Bacus case, the main issue was whether the State legislature had properly exercised its directing powers allowing the establishment of multicounty health districts. The collateral issue was whether there was a proper delegation of discretionary powers to local health departments to enact rules and regulations. Although the court upheld the Montana statute insofar as the combining of counties was concerned, the court invalidated the statutory provisions which authorized county and district boards of health to enact rules and regulations " pertaining to the prevention of disease and the promotion of public health' but in the areas of their jurisdiction 'in no instance shall such rules and regulations be less effective than, nor in conflict with, rules and regulations promulgated by the State board of health" (22b). The court did not believe that this provision was sufficiently definite to lay down proper standards for the guidance of the agency in areas where the State board of health had not acted. The court quoted from a legal encyclopedia (220):

. . . in order to avoid the pure delegation of legislative power by the creation of an administrative agency, the legislature must set limits on such agency's power and enjoin on it a certain course of procedure and rules of decision in the performance of its functions and, if the legislature fails to prescribe with reasonable clarity the limits of poucer delegated to an administrative agency, or if those limits are too broad, its attempt to delegate is a nullity. . . . On the other hand, a statute is complete and validly delegates administrative authority when nothing with respect to a determination of what is the law is left to the administrative agency, and its provisions are sufficiently clear, definite, and certain to enable the agency to know its rights and obligations. [Emphasis as given.] 
There is no universal formula for determining how much discretionary power may be delegated, but the power cannot be absolute, unregulated, or undefined. Discretionary power allows the agency to exercise its own judgment within defined statutory limits. The power to make or alter the laws, which involves discretion as to what the law shall be, cannot be delegated. Nor may an agency be empowered to declare what shall constitute a crime or how it should be punished. Criminal punishment for violation must come from the legislature.

Rules, regulations, and orders issued by administrative agencies serve as an extension of the original statute. They must serve the purpose for which the agency was created in order to be valid. Any arbitrary or capricious regulation, which cannot be demonstrated to bear reasonable relation to the purpose for which the agency was authorized, will be voided by the courts. However, valid rules, regulations, and orders have the force of law. They are binding on all persons coming under their jurisdiction and the courts take judicial notice of them $(\mathscr{Q} c)$.

A specific example of the court's backing of an agency in its exercise of its properly defined discretionary power is illustrated in Gulino Construction Corporation v. Hilliboe (23). The State public health law specifically required that the New York State Health Department approve plans for realty subdivision, to see that they showed adequate sewerage facilities and that the installation was in accordance with the approved plans. Gulino acquired 85 acres of land in Camillus, N.Y., for the purpose of subdividing the land into tracts and erecting homes. The State health department approved Gulino's plans creating a tract known as "section 1" of Oak Ledge Manor, consisting of approximately 36 lots in which the homes were to be equipped with individual sewage disposal facilities. After a number of houses had been built, Gulino submitted similar plans for section 2 to the State health department. The department refused to approve the plans pending formation of a sanitary district and town collecting sewer district to serve Oak Ledge Manor. Gulino brought legal proceedings to ask for an order directing the State health commissioner to file and approve the plans for the proposed realty subdivision, section 2. As a defense to this proceed- ing, the health department stated that it had issued a "Statement of Policy for Realty Subdivisions . . ." notifying the builders of realty subdivisions in the county of the new sewage requirements, and that the proposed sewage facilities for section 2 did not meet the requirements. It argued that the population of the town of Camillus had greatly increased since the approval of the sewage facilities for section 1 and that, with the changed conditions, the approval of septic tanks without adequate planning and construction of public sewers would impose a hardship on the purchasers of these homes and lead to unsanitary conditions.

In upholding the State health department, the court said (23a) :

It seems apparent that under Section 1116 of the Public Health Law, . . . it is for the State department of health to determine whether or not the submitted plans show adequate and satisfactory sewerage facilities, and its judgment thereon should not be disturbed, excepting where its action is arbitrary, tyrannical or unreasonable. ... It must be conceded that the department of health . . . is charged with duties of the highest importance, to wit: to protect the public health. In its capacity of protection of the public health, it has instituted a policy relative to realty subdivisions. . . It is significant that the final decision (based on that policy) will depend upon soil conditions, the size of the subdivision, the rapidity with which it may be developed and other conditions.

Enabling powers. Enabling powers are those which give an agency power to regulate a particular area. The chief application of this power is the granting or denying of a license; thus enabling powers are sometimes called licensing powers.

A State legislature, in the exercise of its police power, for the purpose of obtaining revenue, or both, may require the securing of licenses before individuals may engage in certain occupations or be granted certain privileges. This power of requiring licenses may be delegated by the legislature to political subdivisions of the State, such as counties and municipal corporations.

The licensing process has become a powerful administrative device in the safeguarding of public health $(\mathscr{D} d, 3 f)$. Under the proper enabling legislation, licenses may be granted or revoked under conditions imposed by public health officials, provided the officials' actions do not become oppressive, discriminatory, or arbi- 
trary. Licensing powers generally permit public health agencies to adopt rules and regulations prescribing minimum standards to be met by the licensee in offering health services. Public health authorities are constantly surveying and raising these minimum standards in the interest of the welfare of the community.

An applicant for an occupational license in the health field generally must obtain approval by a State board showing that he has met certain requirements of education, experience, or examination (\$4). The public health objective of the occupational licensing procedure is to protect the public from incompetence, fraud, and dishonesty (25). Some of the major health professions subject to licensing are physician, dentist, nurse, sanitarian, medical technician, physical therapist, psychologist, optometrist, pharmacist, social worker, and others. This list is never exhausted, for each session of the legislature adds additional healthrelated occupations.

Another type of licensing program in the interest of public health gives the licensee the privilege of placing potentially hazardous products on the market with prescribed safeguards. This is the prelicensing program incorporated into the Federal Food, Drug, and Cosmetic Act (26) as a result of the premature marketing of a drug which caused more than a hundred deaths.

In 1938 Congress outlined a procedure in the New Drug Application provision of the Federal Food, Drug, and Cosmetic Act (26a) which has served as a model for the Pesticide Chemical Amendments of 1954 ( $\left.\mathscr{Q}^{\prime}\right)$, the Food Additive Amendments of 1958 (28), the Color Additive Amendments of 1960 (29), and the Drug Amendments of 1962 (30). Under the system, industry is required to make thorough tests of new products and to submit the results on an application to the Federal Food and Drug Administration. The Administration reviews the data and takes one of three steps: it approves the product and grants permission for its marketing, it issues a regulation prescribing conditions under which the product could be marketed, or it denies approval altogether if it appears that the substance might be unsafe even when properly used or that it might deceive the consumer. The introduction into interstate commerce of a product without prior governmental approval will result in prosecution under the remedial provisions of the Federal Food, Drug, and Cosmetic Act.

A third type of licensing undertaken by public health authorities regulates the operation of institutions and facilities which are subject to health and sanitary laws. Institutions of this sort include restaurants, food processing plants, waste disposal plants, laboratories, clinics, nursing homes, hospitals, and others. In this particular area, there is an active trend to raise minimum standards. That the new standards are constantly subject to questioning in the courts is illustrated in the case of Engelsher v. Jacobs (31).

The case involved an action by a private hospital to compel the New York City Hospital Board to issue a license permitting the operation of the hospital. The board had denied the license because the hospital had not complied with the new regulations of the hospital code which had become effective in 1956 . The hospital had been constructed in 1929 and had been operating under a license since that date. The hospital took exception to the new regulations which required that in other than private rooms each bed must have a floor area of 70 square feet. The problem for the petitioner, introduced by this requirement, was that the hospital contained numerous private rooms designed for two patients with a space area of 125 square feet (62.5 feet to each bed). Unless the hospital was rebuilt in these areas, the consequences of the regulation would be to reduce the bed capacity from 130 to 100 beds. The petitioner argued that the new regulation was unreasonable and constituted an unlawful taking of private property without due process of law.

In upholding the board, the court said (31a):

The police power of the State is the least limited of all the powers of government. . . . It is clearly settled that in no case does the owner of property acquire immunity against the exercise of the police powers because he constructed it in full compliance with existing laws [citations]. . . . The only question then that we must consider in this case is the reasonableness of the regulations. There can be no doubt that they are calculated to promote the health and welfare of the public generally ... the main loss here is the loss of future profit. We cannot say as a matter of law that 
the minimum space requirements are unreasonable. ... The Board of Hospitals did not act in an arbitrary manner in refusing a license.

Summary powers. Summary powers are those which permit an administrative agency to apply compulsion or force against a person or his property to effectuate a legal purpose without securing a judicial warrant to authorize such act. Many State boards of health, as well as local boards of health and health officers, have summary powers to require isolation and quarantine of communicable diseases, to immunize and vaccinate against communicable diseases, to make investigations, to abate nuisances, to forbid gatherings in the interest of public health, to collect vital statistics, and to require disease reports $(3 g)$.

Through the past few decades courts have supported and extended the reasonable exercise of summary powers of the States and their subdivisions in the field of public health. A recent case in point is Gamble v. State (32). Under a 1909 statute, the health board of Gamble's county had in 1932 promulgated regulations requiring immunization against certain diseases. In 1957 , poliomyelitis was added to the list. A resolution by the board, after providing for immunization as a condition precedent to the right to attend school, provided that a survey be made to ascertain those children who needed immunization and that notice be sent to the parents whose children had not been immunized. The school nurse made the survey and sent the required notice. Gamble received two notices but refused to have his children immunized for poliomyelitis. Pursuant to the regulations the county health officer instituted certain legal procedures against Gamble designed to carry out the purposes of the regulations.

Gamble was convicted of violating the regulation and appealed to the Tennessee State Supreme Court on the question that the regulation and the 1909 statute under which it was promulgated were unconstitutional.

The State supreme court upheld the statute and sustained the conviction. The court gave reasons for assigning broad authority to the board of health when it said $(32 a)$ :

We think this is a complete statute in itself [providing a penalty clause for violation of a rule or regulation]. That is, the statute creates a County Board of Health and provides in effect that the health is to be safeguarded by the passage of rules deemed by said Board of Health suitable for conserving the public health and by enforcing the rules and regulations for the State Board of Health. These are regulations that fall under the police powers and wide discretion may be given such Boards. It is not always feasible for the legislature to know what detailed provisions and requirements should be made, especially when emergencies arise.

One major argument against compulsory health regulations is interference with freedom of religion (.33). The present position of the courts was expressed by the U.S. Supreme Court in Cantwell v. Connecticut (34) :

The Constitution inhibition of legislation on the subject of religion has a double aspect. On the one hand, it forestalls compulsion by law of the acceptance of any creed or the practice of any form of worship.... On the other hand it safeguards the free exercise of the chosen form of religion. Thus the Amendment embraces two concepts-freedom to believe and freedom to act. The first is absolute, but, in the nature of things, the second cannot be. Conduct remains subject to regulations for the protection of society.

Under this criterion, which will doubtlessly be tested further, it appears that health legislation based upon police powers is unconstitutional on the question of religious freedom only if it violates the "freedom to believe."

\section{Common Law}

Common law grew up over the centuries in England as a result of the fact that statutory law was in many cases too general to be directly applied to particular cases. It developed as judges used established customs of the community as guides in making specific decisions. As the common law grew, there developed the doctrine of "stare decisis" (the decision stands) whereby a rule of law, whether based upon custom or on being recognized by the courts, formed a precedent which should be followed in all similar cases thereafter unless subsequently overruled by the courts or repealed by the legislature $(2 e)$.

An important branch of common law with which health administrators are increasingly involved is negligence ( $\mathscr{f}, 3 h)$. Negligence revolves around the principle "duty of due care" which a reasonable man in a position of responsibility owes to others. A professional 
man, for instance, is required to exercise that degree of care which professional men of the same calling generally exercise when working in a similar situation. A professional man is not liable for errors of judgment, but the degree of care required of him increases according to the degree of skill he professes.

Until comparatively recent times, health administrators in governmental employ have enjoyed immunity regarding negligence suits. Common law ruled that the king can do no wrong, and therefore sovereign governments historically have not been liable for negligence of their employees. However, by virtue of the Federal Tort Claims Act of 1946, as amended, the United States gave its consent to be sued for the negligence of employees working within the scope of employment. Most States subsequently passed similar legislation, and in instances where they have not, the courts sometimes waive governmental immunity.

In some areas of operation, local governments have retained immunity from suit, and in some areas they have not. Generally it may be said that branches of local government are liable for torts committed by employees in the exercise of purely corporate or proprietary functions (for example, State sale of liquor), whereas they are not liable for torts committed in the performance of governmental functions.

Increasingly, however, the courts tend to create liability in areas formerly immune; an example is the increasing number of successful negligence suits against county-or city-operated hospitals (35).

Public health officials, with their growing vulnerability to suits, would do well to be aware of some of the recent legal history in connection with medical mass screening programs (36). Mass screening, by such devices as $\mathrm{X}$-ray (tuberculosis), Papanicolaou test (cancer), urine and blood tests (diabetes), or tonometry (glaucoma), is an important tool in public health in dealing with disease at early stages. The essence of mass screening is its reliance on a single medical procedure to which every screenee is exposed. The specific procedure is selected for its medical effectiveness as a method of detection and the feasibility of its rapid application to numerous persons. However, the very nature of screening creates two major problems: the so-called false negatives and the false positives.

The results of any screening program will yield initially two, but ultimately four groups. The largest of the four is the true negative group-those who are told accurately that they have shown none of the danger signs being sought and do not have the disease in question. The second group is the true positive, those whose test results warrant further study and who are ultimately determined to have the disease being sought. The third and fourth groups are the false counterparts to the first two: the false negatives are incorrectly classified as not having the disease, and the false positives are notified that their conditions warrant further study although they do not have the disease $(36 a)$.

The issue of false negatives was raised in Battistella v. Society of The New York Hospital. (3\%). An employer gave prospective employees a prehiring physical examination that included a $31 / 2$ " by $41 / 2$ " chest X-ray, the standard size used in mass chest surveys. The two readers of the film did not spot a tubercular indication, and the employee was put to work on a job that aggravated his condition. Later he sued his employer for negligence in failing to tell him that he had tuberculosis and in assigning him to the tuberculo-aggravating job. It was admitted that the spot might well have been detected had a $14^{\prime \prime}$ by $17^{\prime \prime} \mathrm{X}-\mathrm{ray}$, common in private practice, been taken.

The trial court granted judgment to the employee, but the appellate court reversed the decision. The appellate court took notice that economic considerations apparently rule out use of the large size $\mathrm{X}$-ray pictures; the opinion shows an awareness of the practical problems of mass screening and indicates that the court would not require the same protections for the plaintiff that it would require for a private patient in the traditional physician-patient relationship.

The issue of false positives in mass screening has not been litigated to date. However, if negligence could be shown, what sort of liability might follow? The claim would probably be twofold: first, the plaintiff, as a result of the false positive, expended money to undergo a full-scale diagnosis only to find out that there 
was nothing wrong with him, and, second, he suffered psychological injury from the anxiety caused by the letter of notification that he was positive as to the test (36b.)

The real problem of false positives is raised by the possible claim of anxiety, especially in light of the recent New York case, Ferrara v. Galluchio (38). In that case, the physician negligently treated the plaintiff's shoulder wound. It failed to heal properly, and plaint iff erentually went to a dermatologist who told her not to neglect the wound lest it become cancerous. The plaintiff subsequently sought damages from the defendant (the original physician) for both the negligent treatment of the shoulder and for cancerophobia, which she claimed she had developed after the dermatologist's warning. There was no claim that plaintiff had or would get cancer, only that she suffered from cancerophobia with possibly permanent anxiety symptoms. The court of appeals upheld a jury award of $\$ 10,000$ for the original negligence in treatment, plus $\$ 15,000$ for the cancerophobia.

What legal implications can be drawn from the two cases which can be applied to mass screening programs being conducted by public health agencies?

The Battistella case indicates that the court would recognize that screening is quite different from the traditional concept of diagnosis. Diagnosis is personalized; the question is what ails the particular patient, and he may undergo several different procedures to find the answer. In screening, on the other hand, one procedure is applied rapidly to many persons. The court will accept the assumption that screening can be effective only if it relies on predetermined standards of presumptive normalcy that will be accurate for the vast majority of the population. The courts will probably accept the false positives and negatives inherent in mass screening procedures.

The Ferrara case indicates that the actual wording of notification to the screenee should be stated with care. Letters to negative screenees should stress the positive aspects of screening-the idea that screening is mainly geared to finding people who have a particular symptom of a particular disease and not in negating the disease in others. The necessity for periodic tests should be emphasized, so that no screenee can possibly be misled as to what was done to him and what value it has for the future. Notification to the positive screenees should be sufficiently alarming to get them to see a physician for full diagnosis, but should not frighten the recipients unduly. This letter might even quote a statistic, such as that two of every three people receiving a positive result on a screening test do not have glaucoma, but that the recipient should see his physician just to make sure. Such a letter should serve to allay fears and prevent or minimize any reaction such as that proved in the Ferrara case (36c).

\section{Conclusion}

What is it possible to say regarding the future of community health law?

Health laws, as they are enacted under State and Federal constitutions, are dynamic responses to changing community environment. Legislation will continue to be proposed, adopted, amended, and replaced, according to advances in scientific technology and new social trends. The scope of public law will doubtless expand. Matters formerly adjudicated under common law, such as nuisances, are increasingly covered by specific statutory regulations, and it is safe to assume that this trend will go on. It is also to be expected that legislatures will grant increasing degrees of police power to health agencies.

The courts will closely scrutinize controversial delegations of power to see that their scope is clearly defined and that they are subsequently reasonably wielded by the health agency involved. It is to be hoped that health administrators who are both knowledgeable and wise will be available to act upon the broadened mandate of the public to solve tomorrow's health problems.

\section{REFERENCES}

(1) Hamlin, R. H. : Public health law or the interrelationship of law and public health administration. Amer J Public Health 51 : 1733-1737, November 1961.

(2) Hanlon, J. I.: Legal considerations in public health. Ch. 8. In Principles of public health administration. Ed. 3. C. V. Mosby Co., St. Louis, Мo., 1960 ; pp. 194-224; ( $a$ ) pp. 203-204; 
(b) pp. 207-209; (c) pp. 213-216; (d) pp. 210211 ; (e) pl. 197-198; ( $f$ ) pp. 216-218.

(3) Tobey, J. A.: Public health law. Ed. 3. The Commonwealth Fund, New York, 1947; (a) pp. 15-37; (b) pl. 40-44; (c) pp. 44-57; (d) pp. 359-375; (e) pp. 58-114; (f) pp. 90-92; (g) pp. 119-278: ( $h$ ) pl. 279-321.

(4) Edelman, S.: Legal problems of planning in metropolitan areas. Public Health Rep 77 : 689-697, August 1962.

(j) Huron Portland Cement Co. v. Detroit, 362 C.S. 440 (1960).

(6) Jacobson v. Massachusetts, 197 U.S. 11 (1905).

(i) Gramm, C. F., Jr.: Constitutional law due process-fluoriclation of water supplies. Notre Dame Lawyer 38: 71-78, December 1962; Auchter, J. R.: Fluoridation: A sturly of philosophies. Amer Bar Assoc J 46 : 523-525, May 1960 ; Nichols, A. H. : Freedom of religion and the water supply. Southern California Law Rer 32: 158-176, winter 1959; Dietz, H. A. : Fluoridation and domestic water supplies in California. Hastings Law J 4 : 1-22, fall 1952.

(8) Kaul v. City of Chehalis, 45 Wash. 2d 616, $277 \mathrm{P}$. 2d 352 (19.54) : (a) pl. 355-356; (b) pp. 364365.

(9) DeAryan v. Butler, 119 Cal. App. 2d 674, 260 I. $2 d 98$ (1953), certiorari denied, 347 U.S. 1012 (1954).

(10) Chapman v. City of Shreveport, 225 Ia. 859, 74 So. 2 d 142, appeal dismissed, 348 U.S. 892 (1954).

(11) Dowell v. City of Tulsa, 273 P. 2 d 859 (Okla., 1954), (eertiorari denied, 348 U.S. 912 (1955).

(12) Kraus v. City of Clevcland, 163 Ohio St. 559, 127 N.E. 2d 609 (1955), appeal dismissed, 351 U.S. 935 (1956).

(13) Birnel v. Toun of Fircrest, 53 Wash. 2d 830, 335 P. 2d 819 (1959).

(14) Froncek v. City of Miluaulice, 269 Wis. 276, 69 N.W. 2d 242 (1955).

(15) Bacr v. City of Bend, 206 Ore. 221, 292 P. 2d 134 (1956).

(16) Wilson v. City of Council Bluffs, 253 Iowa 162, 110 N.W. 2d .569 (1961).

(1\%) Readey v. St. Louis County Water Co., 352 S.W. 2d 622 (Mo., 1961), appeal dismissed, 371 L.S. 8 (1962).

(18) City Commission of Fort Pierce v. State, 143 So. 2d 879 (Fla.. 1962).

(19) MeGurren v. City of Fargo, 66 N.W. $2 d 207$ (N. Dak., 1954).

(20) Miller v. City of Evansville, 189 N.E. $2 d 823$ (Ind., $1963)$; Teeter v. Municipal City of La Porte, 236 Ind. 146, 139 N.E. $2 d 158$ (1956).

(21) Greve, C. II. : Provisions of State laws governing local health departments. Public Health Rep 68: 31-42, January 1953; Moldenhauer, R., and Greve, C. H.: General regulatory powers and duties of State and local health departments. Public Health Rep 6s: 434-442, April 1953; C.S. I'ublic Health Service: State laws governing local health departments. PHS Publication No. 299, U.S. Government Printing Office, Washington, D.C., 1953; Mustard. H. S. : Legal aspects of planning for local health units. Amer J Public Health 37 (supp.) 20-30, January 1947; Boyd, R. F.: Iegal aspects [of local health units] from viewpoint of a State health department. Amer J Public Health 37 (supp.) 31-4., January 1947.

(2.) Bacus v. Lalie County, 138 Mont. 69, 3.54 P. 2d 1056 (1960) ; (a) p. 1058; (b) p. 1060 ; (c) p. 1061.

(2.3) Gulino Construction Corporation v. Hilliboe, 8 Misc. 2d 853, 167 N.Y.S. 2d 787 (New York, 1956) ; (a) pp. 790-792.

(2.1) Professional and occupational licensing. California Law Rev 44 : 403-408, May 1956.

(25) Desirability of State licensing of medical technologists. Minmesota Law Rev 44: 1125-1147, Iay 1960.

(26) Public Law 717, 7.th Cong., 3d sess., June 25, 1938; ( $a$ ) Sec. 50.5.

(2ণ) Public Law 518, 83d Cong., 2d sess., July 22, 1954.

(28) Public Law 929, 85th Cong., 2d sess., Sept. 6. 1958.

(29) Public Law 618, 86th Cong., 2d sess., July 12 , 1960.

(30) Public Law 781, 87th Cong., 2d sess., Oct. 10. 1962.

(31) Engelsher v. Jacobs, 5 N.Y. 2d 370. 1.57 N.E. 2d 626,184 N.Y.S. $2 d 640$ (1959) ; (a) pp. 643-644.

(32) Gamble v. State, 206 Tenn. 372,333 S.W. $2 \mathrm{~d} 816$ (1960) ; (a) p. 820.

(33) Rendering unto Caesar: State health regulations and the free exercise of religion. Iniversity of Chicago Law Rev 26: 471-484, spring 1959.

(3.1) Cantwell v. Connecticut, 310 C.S. 296 (1940).

(35) Van Alstyne, A.: Governmental tort liability : Judicial lawmaking in a statutory milieu [Muskopf case]. Stanford Law Rev 15: 163-253 (1963) ; see also Muskopf v. Corning Hospital District, 55 Cal. 2d 211. 359 P. 2d 457 (1961).

(36) Franklin, M. S.: Medical mass screening programs: A legal appraisal. Cornell Law Quart 47 : 205-226, fall 1962 ; (a) p. 222 ; (b) 225 ; (c) p. 226 .

(3i) Battistella v. Society of The New York Hospital, 9 App. Div. 2d 75, 191 N.Y.S. 2d 626 (New York, $1959)$.

(38) Ferrara v. Galluchio. 5 N.Y. 2d 16, 152 X.E. 2d 249,176 N.Y.S. 2 d 996 (1958). 